\title{
REGIONAL AUTONOMY PROLIFERATION OF REGION AND PSEUDO LOCAL GOVERNMENT IN INDONESIA
}

\author{
M. Ali Imron \\ Ritsumeikan Asia Pacific University, Japan \\ Email: imron_fia@yahoo.com
}

\begin{abstract}
ABSTRAK
This paper discusses the other side of the potential negative effects, even failure, of the implementation of the decentralization policy in Indonesia. One cause of the demands to establish a new area is rent seeking, where local elites and local politicians try to regain power through the formation of new regions. One thing overlooked by scholars is the existence of local businessmen who also participated in the formation of new regions. Their presence did not appear as real as the local elites and party elites because they take roles behind the scenes as lenders; the group was later referred to as the "black market." The existence of this black market in the regional areas is always necessary for an area's local elites and political elites to regain power as one force.
\end{abstract}

Keywords: Regional Autonomy, Proliferation of region, Black market, Rent seeking, and Pseudo local government

\begin{abstract}
This paper discusses the other side of the potential negative effects, even the failure of the implementation of the decentralization policy in Indonesia. One cause of the demands to establish a new area is rent seeking, where local elites and local politicians try to regain power through the formation of new regions. But one thing overlooked by scholars is the existence of a local businessman who also played in the formation of new regions. Their presence did not look so real compared to the presence of local elites and party elites, because they take a role behind the scenes as lenders, the group was later referred to as the "black market." The existence of black market in the regional area is always needed by local elites and political elites as one force to regain power.
\end{abstract}

Keywords: Regional Autonomy, Proliferation of region, Black market, Rent seeking, and Pseudo local government 


\section{INTRODUCTION}

Implementation of regional autonomy has given positive and negative impacts. Along with the passage of time, the policy of regional autonomy that emerged after the reform showed many problems, among others, such as coordination problems between local government districts with the provincial government. Decentralization within proliferation policy has led to various cases of horizontal conflicts in various regions. Proliferation cases same time became anarchic issues, for instance in province of North Sumatra is a portrait of the problems surrounding the proliferation, where a demonstration demanding the formation of Tapanuli province on February 3, 2009 has turned into a demonstration of anarchists and culminate is the killing chairman of Regional House of Representatives (DPRD) North Sumatra (Surya, February $3^{\text {rd }}$ 2009). Aftermath of this incident, finally the President issued an instruction to temporarily stopping proliferation policy in Indonesia. According to the President, proliferation policy should not be used for the benefit of the elites or other political motivations (Batam Pos, July $2^{\text {nd }} 2009$ ).

The problems that occur cannot be separated from Law No. 22 of the year 1999 regarding local government is still in the process of transition towards the ideal of regional autonomy. Based on various problems which often occur as a result of implementation of Law No. 22 of the year 1999, the government has change two important laws relating to the implementation of regional autonomy; the first is Law No. 22 of the year 1999 which later amended by the Law No. 32 of the year 2004 regarding local government; the second is Law No. 25 of the year 1999 which later amended by the Law No. 33 of the year 2004 regarding financial balance between Central Government and Local Government. Improvement of legislation intended to reduce negative impacts and increase the value of local autonomy. However, in reality, still cannot answer the issues raised in the area. Direct election of regional head (Pilkada), new products from Law No. 32 year 2004, is the concrete form of political decentralization. Spirit direct elections as an attempt to create a better leadership in the area, more often turns into a new field of political conflict and often lead to social conflicts. Not many areas are able to conduct elections in a peaceful and dignified.

Direct election of regional head began to be implemented in 2004 has brought many changes in the system of democratization in Indonesia. Pilkada has provided a very strong legitimacy for the regional head, so it is hoped will bring a positive impact that closer of the Regional Head with the people who voted, with the expected closeness of regional head will be getting a better understanding of the condition of the people they lead. But in reality, it has raised many serious problems in several areas. One of the problems that interest to be studied is the practice of money politics is mostly done in regional elections in Indonesia, from the nomination as a candidate until the campaign period. Consequently Pilkadal costs that must be spent by each candidate are very large, this does not only tarnish the journey of democracy in Indonesia, but money politic will bring to the low quality of leaders it produces. Thus, the political leader who was born in a corrupt election process will form a government that is not credible. The public will be increasingly not familiar with the political decision-making process, while the political elite will have strong correlation with the interest groups that play to benefit from political decisions.

\section{DISCUSSION \\ Regional Autonomy: The Model of Decentralization in Indonesia}

Indonesia have implemented autonomy policy effectively since January 2001, provides a valuable learning process, especially the essence in the life of building democracy, solidarity, justice, equality, and regional diversity in unity through go- 
vernment encouragement to grow and the development of the early initiatives (regional and community) to welfare of the community. The basic principle of regional autonomy within the framework the regional administrations in conceptions are: delegation authority, the distribution of income (income sharing), power (discretion), diversity in unity (uniformity in unity) local self-reliance, development of local capacity (capacity building). Thus there has been a very fundamental change in the Indonesian system of government from a very centralized government toward a decentralized model of governance.

Indeed, when viewed from the historical side, Indonesia has adopted a model of regional autonomy, look at how the founders of the Indonesian state have been thinking about decentralization, as stated Hatta (1967): according to the basis of popular sovereignty, the right of peoples to selfdetermination does not only exist on central of government, but also in everywhere in town, in the village, and the area .... with that case, then each section or class of people gain autonomy (to create and run their own regulations) and Zelfgbestur (regulations made by the council is higher) ... such circumstances it is very important, because for each place in one country is not the same, but different (Hatta, 1967).

Hatta argument's is very clear, that Indonesia is basically also built within the frame of democracy that later in the implementation of the government system adopted the system of decentralization. This is evident with the making of the Regional Autonomy Law No. 01 year 1945 as the first law of autonomy, but the application of this law could not maximum because of many interests of the central government. Then Soekarno was release Penpres No. 06 Year 1959, which changed the pattern of central and regional relations became centralized and with a very narrow scope. Penpres was later replaced by Law No 18 year 1965 which it is also almost exactly the same can be said Penpres No. 06 In 1959 that centralistic and authoritarian.
During the New Order regime under Soeharto, the condition not different from the Old Order, although in fact the stream of society to gain flexibility in managing the region has responded by MPRS by Decree No. XXI / MPRS / 1966 regarding the real autonomy. But in the fact, MPRS Decree cannot be done, because the Suharto regime in power have been canceled through the MPR Decree No. IV/MPR/1973 by changing the "real autonomy and responsibility." The principle of real autonomy and responsible then elaborated in the Law no. 5 year 1974 regarding Regional Government, which obviously form a pattern of relationships that are not democratic. When the transition to democracy began, following the collapse of the New Order, the spirit of decentralization and local democracy had an awakening. The former law abolished and then replaced by Law no. 22 year 1999, and last amended by Law no. 32 year 2004 the more "concrete" and have the spirit of decentralization and local democracy. Decentralization in the context of Indonesia is believed to be a way to build effective governance, develop democratic governance, respect for the several of local diversity, respect and develop the potential of local livelihoods, and maintain national integration.

\section{Proliferation of region in Indonesia}

There are many experts on political science stated that by implementing decentralization system, Indonesia has been included into "Big-Bang Theory" (quoting a term of Astronomic Theory). Decentralization to be said as big-bang decentralization (Pranab: 2006), because it brings an extraordinary impact on system of governance in Indonesia along with any radical shifts concerning authority and responsibility from central government down to local government both city and regency governments as autonomous areas. Other than that, big-bang decentralization has stimulated the existence of new districts all over Indonesia, well known as territorial reform. It also brings an institutional change implication that is dividing/reforming one 
district into two or three new districts, however, decentralization also enables unification of two to become one; but this has not take place in Indonesia yet. Since the enactment of Law No. 22 and No. 25 year 1999, later replaced by Law No. 32 and No. 33 year 2004, Indonesia began to try a new form of governance that provides a greater role to local government. Therefore, the arrangement of the New Autonomous Region (DOB) has become one important issue, which until now still is the focus of the Government. Structuring DOB is still very synonymous with regional divisions; no one has led to the abolition and merger of the region. Look at the Grand Design of Regional Settlement (Desartada) was the government's attention remains focused on regional divisions that will be done until 2025.

The desire to carry out its mandate regarding the decentralization of power is also bringing a new approach called the proliferation. Proliferation is one of the most important raison d'être for acceleration of regional growth. Since, the first initiation in 1999 up to now there have been 524 new areas registered both for provincial and district levels. Based on the data of the Indonesian Ministry of Home Affairs since 1999 up to present, Indonesia has already passed 205 new districts which consist of 7 provinces, 164 regencies, and 34 cities. Thus, currently the total of regions in Indonesia is 524 regions which consist of 33 provinces, 398 regencies, and 34 cities. Although, in 2009 the President issued a moratorium policy, but the aspiration and desire of people to form new districts are not ended, especially those of outside of Java, such as Kalimantan and Sulawesi. It is noticeable that the enthusiasm to form new regions in Java Island area is not strong compared to that of areas outside of Java Island such as Sumatra, Kalimantan, Sulawesi and Papua.

From table 1, it can be seen that the Sumatra and Sulawesi ranked first and second, and was followed by Kalimantan in terms of the number of proliferation of regions. From a total of 205 new districts until
Table 1.

List of the New Regions in Indonesia 1999-2010

\begin{tabular}{llrrrr}
\hline \multirow{2}{*}{ No. } & \multirow{2}{*}{ Provinces } & \multicolumn{4}{c}{ Number of new autonomous regions } \\
\cline { 2 - 6 } & & Provinces & Districts & Cities & Total \\
\hline 1. & Sumatra & 2 & 61 & 14 & 77 \\
\hline 2. & Java and Bali & 1 & 1 & 8 & 10 \\
\hline 3. & Nusa Tenggara & 0 & 10 & 1 & 11 \\
\hline 4. & Kalimantan & 0 & 22 & 3 & 25 \\
\hline 5. & Sulawesi & 2 & 29 & 4 & 34 \\
\hline 6. & Maluku & 1 & 12 & 3 & 16 \\
\hline 7. & Papua & 1 & 7 & 1 & 9 \\
\hline & Indonesia & 7 & 164 & 34 & 205 \\
\hline
\end{tabular}

Source: Ministry of Home Affair, 2010.

the early of 2010, demand of proliferation of region is still very high, although the President had issued a moratorium to stop temporary the proliferation of region policy because $80 \%$ of new areas considered to have failed (Suara Media, July 15 ${ }^{\text {th }}$ 2010). Yet of course the demands of forming a new region cannot simply be shut down by the government, therefore government through the Ministry of Home Affair tried to make mapping policy of proliferation of region (pemekaran wilayah) what was then called the Grand Design Regional Settlement (Desartada). This design is a breakthrough of government to create the ideal number for local government in Indonesia, given the territory of the Unitary Republic of Indonesia, which has a vast territory. So with a total area proportional to the total area and population in Indonesia, the government through local governments can provide better public services to the community.

Table 2.

List of New Region Planning 2010-2025

\begin{tabular}{llcc}
\hline No. & Kategori & Provinces & $\begin{array}{c}\text { Districs/ } \\
\text { Cities }\end{array}$ \\
\hline 1. & Sumatra & 2 & 10 \\
\hline 2. & Jawa & - & 7 \\
\hline 3. & Kalimantan & 2 & 10 \\
\hline 4. & Sulawesi & 2 & 11 \\
\hline 5. & Bali-Nusa Tenggara & - & 3 \\
\hline 6. & Maluku & - & 4 \\
\hline 7. & Papua & 8 & 54 \\
\hline
\end{tabular}

Source: Ministry of Home Affair, 2010. 
Table 2 above shows that the still high public demands of proliferation of the region throughout the territory of Indonesia. Sulawesi and Kalimantan and Sumatra islands still dominate the highest rankings to create new region. In accordance with data of grand design of Regional Settlement has been issued by the Ministry of Home Affairs until the year 2025 there will be the addition of new areas including; Province will increase 8 new Provincial, district will increase 54 city/region. Thus, until 2025 Indonesia will have 40 provinces and 545 cities/regencies.

Proliferation of region also meant to strengthen the base of the implementation of government tasks in the area. As intended that regional autonomy has willed to give management authority to local governments, proliferation has the goal of keeping the central area of authority is not located in places that are too far from the presence of base communities. Thus, proliferation has meant that government's attention can be done more effectively, efficiently and with quality. Proliferation wish to cut the distance between the centers of power to the outermost point of the area included in the scope of its authority. Areas that are part of the country are the tip of the spear and a benchmark for changes in Indonesia, hence strengthening the bases in the region is the right strategy to pave the road to prosperity.

Out of the above issue, on the other side, within decentralization discourse, proliferation of the region is regarded as one of important aspect of the implementation of regional autonomy. The purposes of forming new district itself refer to the existed Act, which can be classified as followings: (1) there is a desire to provide a better public service in a measureable/limited authority area. The service approach through a new district's government is assumed to be able to provide a better service; (2) accelerating economic growth of local people through improvement on framework of economic growth of area with local potential base; (3) absorbing more labor force into private sectors, government and power sharing in terms of politics and governance (Hermanislamet, 2005).

From various public discourse and academic studies many described encouragement proliferation of region came from the demand for more regional rather than central government initiatives. As revealed by Putra (2006) and Pratikno (2007) that the main reason for the proposed Proliferation of region are: first, the need for regional economic equality. According to IRDA data, the need for economic equality becomes the most popular excuse used to split a region. For example, the case of forming new region of North Minahasa in North Sulawesi Province. This reason is also widely used for proliferation of region, especially outside Java Island that there were gaps in terms of its economy with the island of Java.

Second, geographical condition that is too broad. Many cases in Indonesia, public service delivery process was never implemented with optimal because inadequate infrastructure. As a result a very large area makes the management of government and public services are not effective as in the case splitting Bolango Bone in Gorontalo Province. Java Island is due to the existing wide area so that public services cannot be implemented optimally.

Third, differences base identity. The reason for the difference of identity (ethnicity, home of the offspring) also appears to be one reason for the proliferation. The demand of proliferation arises because usually the people who live in the area to feel as separate cultural communities that are different from the main community of local culture. It can be seen in the case of the formation of South Solok regency in West Sumatra, Wakatobi in Southeast Sulawesi and the formation of Bharat Pakpak district in North Sumatra.

Fourth, the failure of the management of communal conflict. Political turmoil cannot be resolved often creates demand for local separation as in the case of the proposed 
formation of West Sumbawa in West Nusa Tenggara and East Sulawesi province of discourse formation, and so forth.

Fifth, the existence of fiscal incentives which are guaranteed by the Law to new areas where there results of proliferation the region policy through the General Allocation Fund (DAU), profit sharing of Natural Resources, Local Income.

Of the five main reasons for the demands of the forming new region, the reason for economic equality, geographic and region needs to obtain fiscal incentives through the General Allocation Fund (DAU), profit sharing and natural resource revenue is to be the main triggers of many regions wish to be divided.

Table 3.

General Allocation Funds (DAU) for

District and Municipalities in Indonesia 2001-2010

\begin{tabular}{ccccc}
\hline Year & $\begin{array}{c}\text { DAU for } \\
\text { local govern- } \\
\text { ments } \\
\text { (billion Rp) }\end{array}$ & $\begin{array}{c}\text { Number } \\
\text { of local } \\
\text { govern- } \\
\text { ments }\end{array}$ & $\begin{array}{c}\text { Average } \\
\text { DAU } \\
\text { distri- } \\
\text { bution } \\
\text { (billion } \\
\text { Rp) }\end{array}$ & $\begin{array}{c}\text { Average } \\
\text { D AU } \\
\text { increase/ } \\
\text { decrease } \\
(\%)\end{array}$ \\
\hline 2001 & $54,311.22$ & 336 & 161.64 \\
\hline 2002 & $62,243.46$ & 348 & 178.86 & 7.22 \\
\hline 2003 & $69,280.11$ & 370 & 187.24 & 8.38 \\
\hline 2004 & $73,917.81$ & 410 & 180.29 & $(6.96)$ \\
\hline 2005 & $79,888.86$ & 434 & 184.08 & 3.79 \\
\hline 2006 & $131,086.71$ & 434 & 302.04 & 117.97 \\
\hline 2007 & $148,308.66$ & 434 & 341.73 & 39.68 \\
\hline 2008 & $161,556.43$ & 451 & 358.22 & 16.49 \\
\hline 2010 & $167,777.69$ & 477 & 351.71 & $(6.50)$ \\
\hline
\end{tabular}

Source: The Ministry of Finance, 2010.

From table 3, it can be seen that along with the increasing number of regional autonomy would lead to increased of total DAU should be provided by central government. However, if considered at the DAU distribution average, each year the numbers also increased significantly and these are increasingly pushing the region to split the new territory again with the hope for getting incentives DAU. In addition to objective reason for the public interest from the perspective of regions such as proposed earlier, were still a lot of other reasons that trigger the occurrence of proliferation. The desire of power between elite bureaucrat and political elite has given the emergence of political broker or rent seeking (Fitriani, 2005 and Tanje, 2007).

In the last ten years almost all cases the formation of new autonomous regions throughout Indonesia cannot be separated from the motive of rent seeking. With the proliferation of region, elite bureaucrats and political elites are always benefited by opening a new office items. For the bureaucrats of course with the new area will increase open the new campaign, new echelon structural positions and new opportunities. For the political elite will gain increased political resources in the form of a new political office, such as Regional Head, the Chairman and members of parliament. Another thing that is not less important is the reason for the splitting of gerrymandering. Gerrymandering motif is one of the goals of "hidden" from the political elite as a business division in the political area (Bakti in Ratnawati, Tri and Pamungkas, 2007). In this new area intentionally formed with the purpose of providing benefits to a particular party or candidate. The principle used is the maximization of effective votes of supporters and opponents to minimize the effective voice by creating the boundaries of electoral districts.

Indeed, the layers are benefited by the establishment of new area is not just limited to political elites and elite local bureaucrats but also included business people or entrepreneurs regions. As Pratikno said (Mubarak, 2006) that in the case of the formation of new autonomous regions who have never harmed by the proliferation policy is a layer of elites in all components. In this case, the business also benefited from the increased circulation of money in line with the development of economic activities, such as the provision of physical infrastructure and other spending needs. Even the civil society organizations also obtain a new arena in bridging the relationship between communities and local governments. Hope there 
will be new posts and positions this new economic resources being pursued by the majority of politicians, bureaucrats, and businessmen to propose proliferation of the region.

\section{Direct Election of Regional Head (Pilkada)}

The second largest job in the implementation of regional autonomy after proliferation of region is the implementation of direct election of regional head. It is new product from Law No. 32 year 2004, which is a concrete form of political decentralization. The spirit of direct election of regional head (Pilkada) is a form of effort to create better leadership in an area that is more democratic because it is directly elected by the people so that it will create capable and accountable leader who have a high legitimacy that will further encourage the creation of good governance.

Pilkada has given an anomaly in the practice of local democracy. The premise that democracy positively correlated with decreased levels of corruption which in fact does not apply in the context of Indonesia. Corruption is increasing even after the implementation of direct elections. As stated by Adnan Topan Husodo (Deputy Coordinator for ICW), based on Quantitative Data from Corruption Eradication Commission (KPK) shows that since 2005 there are 40 regional head, whether governors, mayors, and regents are to be convicted of corruption cases. While the Office of the State Secretariat reported, until 2010 President Yudhoyono has signed 150 license examinations for regional heads as a witness or suspect cases of corruption (http//forumparlemen.or.id).

When analyzed, the increasing of corruption cases after pilkada actually comes from the use of high cost and unmanageable. In various cases of pilkada in several regions, money has become an important factor in supporting a wide range of activities ranging from nominating a candidate, campaign material procurement, logistics, and to finance campaign team could even say money is the driving force in the Pilkada, without money it is very difficult for a candidate to be the winner in the elections. In a positive function, the money could help candidates reach the seat of power. In Pilkada, the money political practices of the most traditional is buying and selling effort of political party support in the early nominating process.

In the process of partner candidate region head selection, some political party turned into a money machine. As ever written in the "Perahu Pukat Harimau" (Kompas, June $25^{\text {th }} 2007$ ), so the nomination process was opened, the political party was making money for those interested. Similar to trawling (pukat harimau) the amount of got money also varied, ranging from the hundreds of millions of rupiah to billions of rupiah, when the practice of buying and selling boats so massive, many people believe that giving a space for individual candidates would reduce the practice of money politics in the nomination process. In fact, after the individual candidate was accommodated, the practice of buying and selling boats does not necessarily stop. Moreover, with boundary conditions that do not support a light, a candidate for regional head through an individual path is not easy and inexpensive option. Because of the requirement that, although not necessarily free, "get support" from political parties remain attractive options.

Linier with opinion above, Ramlan Surbakti (the former of KPU member) have said that several potential political practices of money (money politics) in the administration of direct local election have to be identified. First, in order to become a candidate is required "rent a boat", whether paid before or after the establishment candidate, in part or entirely. The number of rental to be paid is estimated to far exceed the limits sizable campaign fund contributions stipulated in the Act, but it is not known with certainty because it took place behind the scenes.

Second, the candidate who is expected to receive strong support, usually the incumbent, will receive huge funds from 
businessmen who have economic interests in the area. The amount of money is also far exceeding the contribution limits established by law. Since going on behind the screen, then difficult to know who is giving to whom and how much the funds received.

Third, to districts which number about 10,000 voters and 100,000 voters, but the territory has a high economic potential, entrepreneurs who have economic interests in the area can even determine who will be elected to head region. With the amount of funds that are not too large, the entrepreneur can influence the voters choose the candidate who wants through "political intermediaries" who was appointed in each village.

Fourth, to areas with three or more candidates compete, vote by more than 25 percent to deliver a pair of candidates to be regional head and deputy head of the selected areas. In this situation, using the money influence the voters through "intermediaries' politics" in every village may be the "rational" for the pair of candidates (http// spiritentete. blogspot.com).

The phenomenon of the high cost politics of pilkadal have been agreed by Minister of Home Affair Gamawan Fauzi. He said a paradox between the high costs of pilkadal and demands a government free from corruption, collusion and nepotism. He also said that to become a governor needs funding of about 100 billion Rupiah, while the governor's salary amounting to 8.7 million Rupiah per month (Kompas, July 23, 2010). Indeed, what is conveyed by the Minister of Home Affair is not something surprising, because it was not a secret anymore when to become a candidate of both the Governor and Regent/Mayor need of the high cost. As published in the Kompas, that the implementation of pilkadal in Bandung Regency is expected to cost hundreds of billions of rupiah. Not only 48 billion Rupiah from the budget of Bandung regency issued for the holding of local elections of 2010, tens of billions of rupiah from the pockets of the candidates for regent and deputy regent was pouring. It was like told by the Chairman of the award of the National Mandate Party (PAN) Mukhlis Anwar Bandung regency, on Monday in Bandung (Kompas; July 27 $7^{\text {th }} 2010$ ).

The high cost is certainly not all come from private pockets, but many of them come from contributions of businessman both local and national level as Sebastian Salang (Coordinator of Community Care Forum Indonesian Parliament) was said that some employers still support the candidate whose orientation is materialistic and not rely the power of ideas. This is because some businessman that has economic interests if elected the candidate it supports. (Kompas, July $24^{\text {th }} 2010$ ).

\section{Appearance of Pseudo Local Gover- nance}

Pseudo government first recognized during the Second World War when the Soviet Union recognizes the existence of a puppet government, this term is then more famous by the name of pseudo-government as a shadow government of the actual administration (Harold, 1968). In further developments this term continues to grow until eventually the term hybrid organization to illustrate the existence of the pseudogovernment. Hybrid organization is a body that operates in both the public sector and the private sector; simultaneously fulfill public duties and developing commercial market activities. As result the hybrid organization becomes a mixture of both a part of government and commercial enterprises (Jacqueline; 2008). The existence of pseudo-government has promised an increase in efficiency and good service for the implementation of the tasks of government. It has grown and emerged as a new entity that receives delegation of government functions, so that activities occurring in the merger between the public and public sector organizations.

By contrast, Koppel argued that when the policy carried out by a hybrid organization, the actual control of the government's policy has been sacrificed. Even though hybrid organization is designed to limit the 
loss of public control, but the existences of hybrid organization should be limited to tasks that are not very important for policy makers (Koppel; 2003). He apparently realized that the existence of a hybrid organization is not absolutely good for the government itself, and it should have certain limitations, so that its existence would not be stronger than the actual government. In the understanding of Pseudo government in Indonesia, this terminology is used to describe the condition of weak governance as a result of the control of a handful of people who lead the government in the shadow of other powers. Koppel expectations did not materialize in Indonesia, because in reality a pseudo government in Indonesia is more powerful influence in the process of policy rather than actual governance. The presence of pseudo local government in Indonesia was marked by strengthening of the role of businessman in the process of regional proliferation as well as in direct election of regional head.

The rise of demands for make new region is a logical demand if it is related in order to improve public services and welfare of the community. However, if examined from the other side as in the theory of rent seeking and gerrymandering, the demand for proliferation of region as big question mark, is it true that all who want society? Or just the opposite that which wants it just a group of local elites and political elites and entrepreneurs who want to get the benefits of either position or material gain. One thing to be a consequence of proliferation of the region is the division of authority over natural resources, human resources and budget. The consequences of the division often make the implementation of proliferation of region have follow-up impact of conflict of interest. It is possible also that proliferation is only for a group of elite interests in the region including entrepreneurs, to take possession of power that cannot be obtained if the area is not divided.

With the formation of new autonomous regions (DOB), the next will bring up new political entrepreneurs who cannot be separated from the proliferation process of DOB. At the beginning of the proliferation process, the fighter group about new region requires for greater financial support for the proliferation costs, as well as for other costs. For that is usually a group of "fighters of splitting" will attract several businessmen. Perhaps businessmen are political leaders, local elites, but it could be the businessman's really a pure businessman. After the area that they fight to be formed, for these entrepreneurs will emerge as contractors in construction projects DOB indeed have the physical development program. In addition, these entrepreneurs began to continue the "dominance" in the area of politics and government. From here began to appear a number of new political entrepreneurs. The emergences of new political entrepreneurs create a different impact depending on the position he held. On the one hand, new political entrepreneurs to strengthen civil society but on the other hand can actually weaken the position and role of civil society to criticize government policies in the DOB (Lesung, 2009).

Table 4

Effect of Proliferation Policy to Actors

\begin{tabular}{|c|c|c|c|}
\hline \multirow{2}{*}{$\begin{array}{l}\text { The implications } \\
\text { of regional } \\
\text { autonomy }\end{array}$} & \multicolumn{3}{|c|}{ Actors } \\
\hline & Local Politicians & Local Elites & Businessman \\
\hline \multirow[t]{2}{*}{$\begin{array}{l}\text { Proliferation } \\
\text { Policy }\end{array}$} & $\begin{array}{l}\text { Taking advantage of new areas to } \\
\text { maximize the party vote in } \\
\text { general election }\end{array}$ & $\begin{array}{l}\text { Taking advantage of the return of } \\
\text { the influence of power that has } \\
\text { faded }\end{array}$ & $\begin{array}{l}\text { Taking advantage of physical } \\
\text { development projects, after create } \\
\text { the new region }\end{array}$ \\
\hline & Targeting new political positions & $\begin{array}{l}\text { With the issue of indigenous } \\
\text { people "Putra Daerah" whom } \\
\text { shall be given a golden } \\
\text { opportunity for the local elite } \\
\text { back in power }\end{array}$ & $\begin{array}{l}\text { Business expansion, and } \\
\text { exploration of local natural } \\
\text { resources }\end{array}$ \\
\hline \multirow[t]{2}{*}{$\begin{array}{l}\text { Direct election } \\
\text { of regional head }\end{array}$} & $\begin{array}{l}\text { Open opportunities to occupy a } \\
\text { strategic political position }\end{array}$ & $\begin{array}{l}\text { Restoring power was lost / faded } \\
\text { and returned to local authorities }\end{array}$ & $\begin{array}{l}\text { Handling of the physical } \\
\text { development projects area }\end{array}$ \\
\hline & & & $\begin{array}{l}\text { Influencing of policy for business } \\
\text { purposes }\end{array}$ \\
\hline
\end{tabular}

Source: Author 
Table 4 presents an overview of how the proliferation policy and direct election of regional head have provided benefits to the actors in the area, both local politicians, local elites, and the businessman. For local politicians will earn a profit by maximizing the party vote in election and to obtain new space for a new political position. As for the local elite will obtain an opportunity to regain lost influence and power through political positions are available. While for the businessmen would more aggressively to get the advantage because they have rendered in the formation of new region, generally they get the advantage of taking advantage of physical development projects and opportunities to explore natural resources owned by the new area. The role of businessman will continue when the results of the proliferation of region has developed. As known in accordance with the mandate of Law no. 32 year 2004, regional autonomy should hold direct election of regional head (pilkada), this is where their role recalculated.

The existence of businessman as provider of funds (black market) in the political area cannot be avoided. This is due to the occurrence of very high political costs both in direct election of regional head (pilkada) or election of members of the legislature. In practice the use of political funds in the form of money politics into something that is difficult to be avoided because many factors of which there are many gaps that facilitate the practice of money politics. Conscious or not, campaign finance regulation is one of the substance of the laws that are not worked seriously. As we know, almost in every discussion of the draft electoral law (whether legislative, presidential, and regional head) legislators never seriously and are reluctant to explore crucial problems that led to the rise of money politics. Moreover, the act was not easily categorized as a crime. It is related to the difficulty of physical evidence obtained as well as the weakness of the existing rules.

And what's worse, is that the candidate of Regional head is not just supported the funding by business circles, but it turns out the local-level bureaucrats also played, it will raise complex issues in the future remuneration for elected regional head. Political Party cannot be abandoned or whether the organizational side and the individual side, they also have a big share of the election of a candidate for regional head, because political party has a big capital in the form of constituency parties, although in this case cannot be proven in some cases. For example, the Golkar Party as major parties who repeatedly won the legislative elections 2004, turned out in some areas pilkadal always suffered defeat. Of the three elements is what will cause Regional Head hostage in his position as a government because of the debt of gratitude to them, so sometimes the Regional Head of nothing more than a puppet for the donator to satisfy all their desires, so it is no wonder if a lot of policies issued by the Regional Head of the many nuances of the interests of donors.

Table 5.

The Formation of Pseudo Local Government

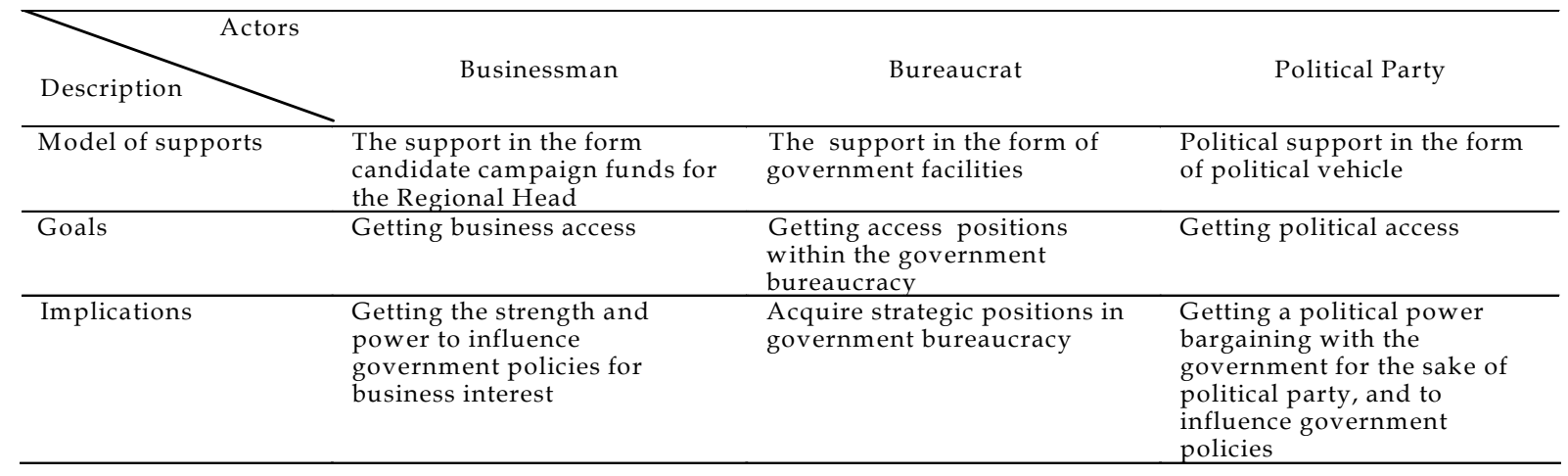

Source: Author 
This conditions which the next will bring up political deals between the political elite with the black market, and then the next would call with Pseudo Government, because of activities occurring in tug of interests between the government and the businessman. On one side, regional head has the task of public welfare, meanwhile black market on the other side that has the objective to achieve profitability. As a result, we see now a lot of the policies adopted by many local governments are not siding with people, which was more beneficial to the entrepreneurs or businessman. This matter as according to what told by Sri Mulyani (the former of minister of finance) that within the political system in Indonesia now, there has been a kind of marriage or in other term is called a cartel that has spawned the barter of interests between businessman and the government (Kompas, May $5^{\text {th }} 2010$ ).

Fecklessness of regional head to businessmen is based more on debt of gratitude, which at the time of direct election of regional heads are generally candidate have received funds from them. Consequently, when they have become regional head, the authority they have held hostage, especially in making public policy, in which they must comply with the interests of businessmen. In this case, businessmen can be derived from pure businessmen or politicians who become businessmen, and businessmen who are also politicians. In this condition, barter between policies with business interests occurred in local government system. Indeed a very pitiful condition in Indonesia's local government system, and if this continues over time, it will have a negative impact on government accountability system and would destroy the system of statehood and democratization.

Indeed, with the implementation of direct election of regional head, local leaders are expected to be more accountable to the people who have been selected with more attention to their interests. In reality, the regional head was more concerned with the interests of political parties and businessmen who have contributed to making them as local leaders. This condition cannot be separated from the practice of money politics in local elections. In addition, money politics and interests that cover for regional autonomy policy has emerged "little kings" in local government that tends to engage in abuse of power that ignores the values of ethics in politics, the widespread practice of corruption, transparency and accountability in low level.

\section{CONCLUSION}

The desire to carry out the mandate of political decentralization has brought a new approach called proliferation of region and direct election of regional head (pilkada). Proliferation of region is one of the bright ideas to speed up the growth of the region. Since first implementation in 1999 up to now that 504 new regions are formed, either in the form of provincial and district / city, in hopes of drastic changes to the welfare of society. So there is no excuse for the government to escape responsibility for the welfare of society. Similarly, the direct election of regional head have given emergence of a legitimate leader by directly elected by the people so hopefully will be able to prosper the people who voted.

However, in practice, it turns out great hope of proliferation of the region policy and local elections would have given the emergence of quasi local governance (Pseudo Local Government) which has given the emergence of political cartels and the creation of entrepreneurs towards government control. Pseudo Local Government also has given emergence to the system of government more like dynasty. All this really started from the rampant practice of money politics that actually has attacked the foundations of democracy, destroy the political ethics, and to improve the behavior of the corrupt. 


\section{BIBLIOGRAPHY}

Bardhan, P. and Mookhereje, D., 2006, Decentralization and Local Governamce in developing Countries: A Comparative Perspective, Massachusetts, London England: The MIT Press.

Fitriani, F., Hotman, B., and Kaiser, K., 2005, "Unity in Diversity? The Creation of New Local Governments in a Decentralizing Indonesia," Bulletin of Indonesian Economic Studies, 41 (1), 57-79.

Harold, J. L., 1968, Refelections on the Revolution of our Time, London: Geroge Allen \& Urwin, Ltd.

Hatta, M., 1967, Kedaulatan Rakyat, Surabaya: Usaha Nasional.

Hermanislamet, B., 1993, “Desentralisasi Perencanaan Pembangunan dan Otonomi Daerah" dalam Jurnal Forum Perencanaan Pembangunan, Vol.1, No. 2, Desember, Yogyakarta: Puslit Perencanaan Pembangunan Nasional UGM.

Jacqueline, M. E., 2008, “Hybrid Organization and Social Enterprise and Social Entrepreneurship" <http// www.lulu.com>.

Kammeier, H. D., 2002, Linking Decentralization to Urban Development, New York: United Nation Human Settlements Programme, UN-HABITA.

Koppel, J. G.S., 2003, The Politics of QuasiGovernment: Hybrid Organizations and the Dynamics of Bureaucratic Control, London: Cambridge University Press.

Lesung, Edisi Maret 2009, "Dinamika Relasi Sosial Politik Lokal Pasca-Pemekaran Wilayah," Jakarta: Lesung.

Leemans, A.F, 1970, Changing Patterns of Local Government, The Hague: International Union of Local Authorities.

Mubarak, M. Z., dkk. (eds), 2006, Blue Print Otonomi Daerah Indonesia, Jakarta: Yayasan Harkat Bangsa bekerja sama dengan Partnership for Governance
Reform in Indonesia (PGRI) dan European Union (EU).

Pratikno, 2007, “Usulan Perubahan Kebijakan Penataan Daerah: Pemekaran dan Penggabungan Daerah," Policy Paper, Jakarta: Kajian Akademik Penataan Daerah di Indonesia kerjasama dengan DRSP-Depdagri.

Putra, R. A. S., 2006, “Pemekaran Daerah di Indonesia: Kasus di Wilayah Penelitian IRDA," Makalah Seminar Internasional Percik ke-7, Salatiga, Juli 2006.

Ratnawati, T. and Pamungkas, C., 2007, "Pemekaran Daerah dalam Perspektif $\mathrm{Na}$ sional," Laporan Pemekaran Daerah, Jakarta: DRSP dan LIPI.

Steve, L, et.al., 1994, The Changing Organisation and Management of Local Government, London : Macmillan Press Ltd.

Tanje, S., 2007, “Dampak Pemekaran Wilayah Terhadap Lemahnya Pelayanan Publik Sektor Pendidikan di Kabupaten Manggarai Barat," Makalah Seminar Internasional ke-8, Percik, Salatiga, Juli 2007.

\section{Other Sources:}

Direktur Jenderal Otonomi Daerah, 2010, Potret 57 DOB: Sebuah Hasil Evaluasi Dini Perkembangan 57 Daerah Otonomi Baru. Jakarta: Dirjend OTDA.

Undang-Undang No. 22 Tahun 1999 tentang Pemerintah Daeah.

Undang-Undang No. 32 Tahun 2004 tentang Pemerintah Daerah. 